\title{
An Applied Study: Investigate the relationship of cash flows, capital expenditure and the ratio of shares issued according to the price coefficient (Case Study: Companies Accepted in Tehran Stock Exchange)
}

\author{
Mahmood Hematfar'
}

' Associate Professor, Borujerd Branch, Islamic Azad University, Borujerd, Iran - Dr.hematfar@yahoo.com

\begin{abstract}
The interests of an investor in an enterprise include: Future earnings, future cash flows and paying future cash dividends, Investing in these interests is demanded by investors and awareness of both the profit and future cash flows draws more attention. The purpose of this study is to investigate the effect of cash flows, capital expenditures and stocks on the price coefficient. This research is an applied research in terms of purpose it also falls into the descriptive-correlational research group in terms of inferring research hypotheses, combined regression models and panel data were used to test the hypotheses, multivariate linear regression test (yearcompany) was used to test the hypotheses. It is a library and analytical-scientific study based on panel data analysis (panel data). After collecting the required information from the companies involved, the research hypotheses were analyzed using correlation and regression analysis and data analysis panel method, initially, preliminary calculations were performed in Excel software and the data was prepared for analysis, then $10 \mathrm{E}$ views software was used to perform the final analysis. In this study, financial information of 101 companies listed in Tehran Stock Exchange during the period 1391 to 1396 (660 companies - year) was reviewed. Based on the analysis carried out to confirm the first hypothesis of the study, we concluded that: There is a significant and direct relationship between cash flows and capital expenditures of companies with respect to the price coefficient of each share. We also concluded that, in support of the second research hypothesis: There is a significant and direct relationship between the ratio of issued stocks and the accumulated cash flows of companies according to the price coefficient.
\end{abstract}

Keywords: Cash flows, the profitability ratio of the investment, Cash capital ratio, Price Coefficient

' Associate Professor, Borujerd Branch, Islamic Azad University, Borujerd, Iran - Dr.hematfar@yahoo.com 


\section{Introduction}

The high amount of free cash flow, as opposed to the financial factor, is the motivating factor for managers' opportunistic behaviors (Asker et al., 2015). Jensen (2005) states that: The existence of free cash flow has a significant impact on the amount of opportunistic behavior of managers. In a situation where the company has a large amount of free cash flow, the manager can invest the surplus funds in various opportunities. Given the limited and reliable return on investment opportunities and value per share, managers are likely to invest in investments that are less profitable than the cost of capital invested or are highly risky (Cummins et al., 2006). Costs that the so-called "free cash flow agency costs" impose on shareholders in this situation (Rhodes et al., 2005). When the company faces a large amount of free cash flow, the amount of managerial opportunistic behaviors also increases. As the financial pressure mounts, this amount of cash will gradually decrease, and as a result, the managers' authority over how to use the company's cash will decrease (March \& Magelloff, 1984). Increasing the ratio of issued stocks to companies is a kind of division of capital into smaller components according to management policies and the discussion of increased investment also comes from the segmentation that is itself an opportunity to create long-term profit (Almeida \& Campbell, 2010). Regarding the price coefficient of each share, transfers and level of cash flows and cash flows, it has also attracted the attention of managers and the implementation of policies based on the long-term goals of the company relies on the adequacy of this variable (Straw, 2002).

\section{Theoretical Foundations}

An investor's interests in an entity include future earnings, future cash flows and future cash dividend payments (Rhodes et al., 2005). Investing in these interests is demanded by investors and awareness of the two benefits and future cash flows is getting more attention. Criteria for evaluating the performance of companies in the capital market can be divided into valuations such as firm earnings, earnings per share, equity returns, return on assets, capital expenditure, and cash flow and so on for successive years to evaluate the 
performance of companies in the capital market (Luata, 2002). Campany management has a variety of sources and ways of financing to provide the necessary funds for capital expenditures and campany operations (Casir, 2015). Among the criteria for accounting performance, cash flow and capital expenditure are the most popular and widely used criteria for accounting performance. Investors seek profit estimates and cash flows from new technologies, are an institution they've invested in, to judge their future cash dividends and equity value based on the opportunities available for similar investments (Falconer \& Petersen, 2006). They need information on future earnings to get an estimate of future cash benefits, because profits are the most important source of information about a company's future profitability (Guerrero \& Scaler, 2011). They need cash flow information to judge their stock value, because most stock valuation models are based on the present value of their expected future cash flows. Accordingly, earnings information and future cash flows are the two benefits of investing in equity demanded by investors and since information on expected cash flows is not available, earnings forecasts are used as a substitute for cash flows (Straw, 2002). The reason for future cash dividends is because it is attempted to relate the price of the securities to the future benefits of the investment. Forecasting future cash dividends is very important in applying many stock valuation models. In this regard, Elson believes that: Only the forecasted dividend distribution can be used as a publicly available attribute for investing in securities; He also believes that the value of securities is a function of expected cash dividends which is adjusted according to the risk (Hutton, 1999). Therefore, according to the material stated, the main research question is as follows:" To what extent is there a significant relationship between cash flows, capital expenditures and the ratio of issued stocks to the listed companies in Tehran Stock Exchange? "

\section{Literature}

Kashanipour, Mohammad, Naghi Nejad, Bijan (2017), the optimal cash reserves equation tries to determine the optimal cash flow of companies considering all available factors. This equation is based on a basic assumption: "Companies have a smart performance and try to keep their cash reserves at optimum level for the benefit of their investors." Given 
this assumption we can conclude that the more efficient the market is and the less representation and information problems there are, companies are more likely to have access to optimal cash reserves.

Arab Mazar Yazdi et al. (2010) investigated the information content of cash and accruals by examining the relationship between stock returns and earnings and its components. The evidence supports the information content of more profits than operating cash flows. Also, the accrual information content of operating cash flows was confirmed. The findings confirm the increasing information burden of voluntary accruals on non-voluntary items.

Mirfakhredin et al. (2016), they compared the ability of cash flows and accruals to predict future cash flows. Their experimental results showed that "Past profits", "cash flows" and "cash flows and accrual components" can be used to predict the future cash flows of companies listed on the Tehran Stock Exchange, However, there is no different capability between the three forecasting models ("profit", "cash flow" and "accrual non-accrual cash flow" regression models). In addition to these additional time periods, accounting data can improve the predictive ability of the model.

Karimi and Sadeghi (2018), in their research, investigated the investment of capital assets and domestic and foreign financial constraints in listed companies in Tehran Stock Exchange. The statistical population consists of 148 manufacturing companies from 1999 to 2008. In this study, the ratio of operating cash flows to equity as internal financial constraints and company size as external financial constraints was used. Analyzing the data and testing the hypotheses using the Error Correction Model (ECM) indicates a significant and positive relationship between firm size and investment sensitivity to cash flows and so with increasing external financial constraints, investment sensitivity to cash flows is also increasing. Other research results show that there is a significant negative relationship between operating cash flow and investment sensitivity to cash flow. Thus, with the reduction of domestic financial constraints, investment sensitivity to cash flows has increased.

Sedaghat Jahanabad et al. (2013), in a study, they examined the impact of cash flows on capital expenditures in listed companies. The statistical population of this research consists of 71 companies listed in Tehran Stock Exchange during the period 2007-2009. In 
this study, to investigate the effect of cash flows on campany capital expenditures from Wong test, multivariate regression was used to analyze the data. The results of their research show that there is a significant positive impact between cash flow and capital expenditure. The results of the Wong test also show that the impact of cash flows on stock price sensitivity increases the level of profitability.

Investigating the combined effect of firm life cycle characteristics on time asymmetry of operational cash flow of Izadinia et al. (2013) shows that combined effect of the characteristics of the firm's life cycle stages on the time asymmetry of operating cash flow is negative and significant. This means that companies that are in the early stages of their growing lifecycles, rather than those that are in the later stages of their adult lifecycles, are no longer asymmetric in operating cash flow. There is a significant relationship between cash flow information and stock returns as well as accrual financial information and stock returns across all life cycle periods shows that during the life cycle of growth and decline, cash flow information is more capable of predicting stock returns than accrual information and the opposite is true of puberty (Hosseini et al., 2013). Ghorbani (2006) examines the relationship between earnings and cash flows with firm value in the context of the firm's life cycle. The results show that in the growth and decline stages, the relationship of cash flows with firm value is stronger than the firm-value relationship and this is true at the stage of puberty.

Belek (1998) examined the relationship between earnings and cash flows with firm value at different stages of the life cycle. In the birth and decline stages, cash flows are more relevant than profits, and this is true at the mature stage. Jenkins et al. (2004) examined the effect of the life cycle on the relevance of earnings components. The results indicate a shift in the relevance of income components to the emphasis on growth in the early stages of the life cycle, emphasizing profitability in the late stages of the life cycle. Aharoni et al. (2006) compared the explanatory power of cash flow-based and accrual-based metrics in explaining firm value at different stages of the life cycle. The results showed that in the growth stage the explanatory power of cash flow-based metrics was higher and in the maturity and declining stages the accrual-based metrics were higher.

Almida et al. (2007), from the relationship between financial constraints and corporate demand for liquidity to develop a new test to examine the effect of financial constraints on 
the impact of business groups on corporate behavior in India. They estimated investment using data from 694 Indian companies over the period 1997-1999 and to obtain evidence that investment sensitivity to cash flow was much lower for business groups. This suggests that business group member companies have better access to foreign funds than other companies.

Chen (2014) examined the impact of increased quality of earnings on the sensitivity of next year's capital expenditure to current accounting profit by selecting 6193 US companies. In this study, it was assumed that capital spending next year would be sensitive to profit this year, therefore the effect of earnings quality on this sensitivity was investigated. The criterion for measuring the quality of earnings in this study was the quality of working capital accruals of the Dicho-Dyecho (2012) model. Where the lower the errors in measuring and estimating circulating accruals, the greater the quality of accruals and the higher the quality of profit. The results showed that earnings quality was positively correlated with capital expenditure. In other words, as the quality of earnings increases, the sensitivity of next year's capital expenditures to this year's accounting profits increases.

Reidick \& Wade (2018) re-examined the sensitivity of corporate cash flow to liquidity and used different empirical and theoretical models in this study; these researchers found a negative relationship between cash asset changes and cash flow. The researchers then compared their results with those of Almeida et al., Which differed in their results. First, the model they used in their research was closer to reality than the model and theories used in Almeida et al., because the model used in these studies could cover a much wider range of capital depreciation rates and cash flow shocks that could be related to productivity. Second, Reedick and Wade correctly stated that when explanatory variables have measurement error, it is possible to change the sign of other anatomical variables. The researchers stated that the sensitivity of the cash flow to cash assets is positive where there is no correction for the Q component (control variable in the experimental model). Following correction of the deviation caused by $Q$ measurement error using GMM estimation, their findings showed negative sensitivity to cash flow. However, in the Riddick and Wade empirical model, control variables such as firm size, capital expenditures, non-cash working capital and short-term debt levels are missing. 
Bidel and Hillary (2015), by selecting a sample of 34 countries, examined how the quality of disclosure of financial information and transparency of accounting information across the country reduces the problem of poor choice and problems related to ethical risk. They also examined the impact of increased accounting information on the sensitivity of capital expenditures to operating cash flows. The results show that as the quality of accounting information increases, capital expenditure sensitivity to operating cash flows increases.

Flore and Harris (2017) examined the relationship between three variables in a study entitled "Liquidity of Assets, Corporate Investment and Internal Financing Costs". They analyzed how the volume, level of liquidity, and level of investment of companies affect internal financing costs. They have studied this on the basis of the Silent Business Theory and between the liquidity costs of an asset and the downstream costs of a corporation; it indicated how asset liquidity had a negative relationship with investment sensitivities.

Castrido (2014) inn his research, using the financial information of 7,176 New York Stock Exchange companies from 1995 to 2013, he examined the relationship between cash flow-investment sensitivity and investment spending. They found that cash flow sensitivity was associated with both less-than-reality investments at a time when cash flows were low, and more than real-time investment when cash flows were high. The ability to fund outside the company has a positive correlation with cash flows and enhances the sensitivity of cash flows. These results indicate that the cash flows of companies facing financial constraints are sensitive when they are in the low cash flow years.

\section{Hypotheses}

There is a positive and significant relationship between cash flows and capital expenditures of companies with respect to price coefficient. There is a positive and significant relationship between the ratio of issued stocks and the accumulated cash flows of companies according to the price coefficient. 


\section{Methodology}

This research is an applied research in terms of purpose. It also falls into the descriptive-correlational research group in terms of inferring research hypotheses. Combined regression models and panel data were used to test the hypotheses; Multivariate linear regression test (year-company) was used to test the hypotheses. It is a library and analytical-scientific study based on panel data analysis (panel data). After gathering the required information from the companies involved, the research hypotheses were analyzed using correlation and regression analysis and panel data statistical method first, the initial calculations were done in the Excel spreadsheet and the data was ready for analysis, Then 10 Eviews software was used to perform the final analysis. In this study, financial information of 101 listed companies in Tehran Stock Exchange during the period 2012 to 2017 was reviewed (660 companies - year). The method of research reasoning is inductive deduction, according to the data type and statistical analysis methods available, the panel data method is used. Because in order to evaluate the effect of cash flows and the ratio of stocks issued by the price coefficient, the predicted and estimated variables are studied from two different aspects. On the one hand, these variables are tested across different companies and on the other hand, over the period 2012-2017. The statistical population of the research is the companies listed on the Tehran Stock Exchange that were admitted to the stock exchange before 2012 and have been active since the beginning of 2012 until the end of 2017 . The data and information of this study are derived from the financial statements of listed companies in the Stock Exchange Electronic Information System.

\subsection{Data collection Tool}

Gathering information is important for any type of research. In this study, to study the theoretical foundations and research background of the research, library method using specialized Persian and Latin books and articles and theses is used. Since the information about the variables in this research includes many of the accounting items contained in the audited financial statements of companies, Required data from financial statements available 
at Islamic Research, Development and Islamic Studies affiliated to www.rdis.ir And Kodal Network, Comprehensive Publisher Information Systems at www.codal.ir, Iran Financial Information Processing Center, www.fipiran.com And the CDs were manually extracted from Stock Exchange Organization.

\subsection{Analytical Model of Research}

The analytical model of the research is generally estimated as follows.

$A F E=\alpha_{0}+\beta i *$ IndependentVariable $+\varepsilon$

$H_{0}: \beta i=0$

The model is not significant

$H_{1}: \beta i \neq 0$

The model is significant

Applied According to Gumplo and Graham's (2013) research, the models have been formulated as follows:

The first model corresponds to the first hypothesis

Investment, $=\alpha_{0}+\beta_{1} Q_{i, t}^{M K T}+\beta_{2}$ Fund $Q_{t}+\beta_{3}$ CashFlow, $+\beta_{4}$ Issuance $+\beta_{5}$ Bubble

$+\beta_{6}\left(\right.$ Issuance $_{i, t}^{*}$ Bubble $)+\beta_{7}$ CapitalStok $_{i, t-1}+\beta_{8}$ Tecbubble $+\varepsilon_{i, t}^{i n v}$

The second model is related to the second hypothesis

CashSaving $=\beta_{0}+\alpha_{1} Q_{i, t}^{M K T}+\alpha_{2}$ Fund $Q_{t}+\alpha_{3}$ CashFlow $+\alpha_{4}$ Issuance $_{t, t}+\alpha_{5}$ Bubble

$+\alpha_{6}\left(\right.$ Issuance $_{l, t}^{*}$ Bubble $)+\alpha_{7}$ CashStock $_{l,-1}+\beta_{8}$ Tecbubble $+\varepsilon_{i, t}^{\text {cash }}$

(Continue...) 
10

\section{Findings}

\subsection{The first hypothesis}

The validity of the whole model considering that the probability value of $\mathrm{F}$ statistic is less than $0.05(0.0000)$ confirms the $95 \%$ significance of the whole model. The coefficient of determination of the model also indicates that $55.42 \%$ of the capital expenditure ratio is explained by the variables entered in the model. Considering the significance of the coefficients according to the results presented in Table 1, since the probability t for the coefficient of variation of cash flows is less than 0.05 (0.0342), As a result, there is a significant relationship between cash flow and capital expenditure ratio at 95\% confidence level. Therefore, the first hypothesis of the research is accepted and with $95 \%$ confidence there is a significant relationship between cash flow and capital expenditure ratio. The positive coefficient of this variable $(0.0342)$ indicates a direct relationship between cash flows and capital expenditure ratio. So, with the increase of cash flows by 1 unit, the ratio of capital expenditures also increases by 0.0342 units. Also, since the probability of t-statistic for the coefficient of variation is less than 0.05 (0.0378), it indicates a significant and direct effect of this variable on the relationship between cash flows and the ratio of capital expenditures. Therefore, based on the analysis performed to confirm the first hypothesis of the study, it can be concluded that there is a significant and direct relationship between cash flows and capital expenditures of companies with respect to price coefficient. The result of the first hypothesis is that there is a significant relationship between independent and dependent variable relationship with Rivier's (2006) and Anderson et al. (2017) studies. But in terms of the type of relationship (direct or indirect), it is related to the results of Griffin et al.'s (2015) research and contradicts that of Fisher's research (2013).

Table 1 - Test results of the first research hypothesis using the fixed effects method

Dependent variable: Ratio of capital expenditure

Views: 660 years - Company 


\begin{tabular}{c|r|r|r|r}
\hline \multicolumn{1}{c|}{ Variable } & Coefficient & T & P-Value & Relation \\
\hline Fixed component & 0.7177 & 6.9640 & 0.0000 & Positive \\
\hline Q Tobin Ratio & -0.0433 & -4.5144 & 0.0000 & Negative \\
\hline $\begin{array}{c}\text { Profitability ratio of } \\
\text { capital expenditure }\end{array}$ & 0.0490 & 5.25 & 0.0000 & Positive \\
\hline $\begin{array}{c}\text { Cash Flow } \\
\text { Ratio of stocks issued }\end{array}$ & -0.3317 & -2.8066 & 0.0052 & Negative \\
\hline $\begin{array}{c}\text { Contrast the ratio of } \\
\text { published stocks and the } \\
\text { price coefficient }\end{array}$ & 0.6133 & 2.8395 & 0.0047 & Positive \\
\hline $\begin{array}{c}\text { Cash capital ratio } \\
\text { Price coefficient }\end{array}$ & 0.0423 & 3.4528 & 0.0006 & Positive \\
\hline $\begin{array}{l}\text { Model coefficient of determination } \\
\text { Statistics F Falue }(0.0000)\end{array}$ & 0.0302 & 0.7765 & 0.0378 & Positive \\
\hline
\end{tabular}

\subsection{Second hypothesis}

The validity of the whole model considering that the probability value of $\mathrm{F}$ statistic is less than 0.05 (0.0000) confirms the 95\% significance of the whole model. The coefficient of determination of the model also shows that $49.08 \%$ of the cash flows accumulated by the variables entered in the model are explained. Considering the significance of the coefficients according to the results presented in Table 2 , since the probability of t-statistic for coefficient of variation of published stock ratio is less than $0.05(0.0001)$, As a result, there is a significant relationship between the ratio of issued stocks and accumulated cash flows at $95 \%$ confidence level. Therefore, the second hypothesis of the study is accepted and with $95 \%$ confidence there is a significant relationship between the ratio of issued stocks and accumulated cash flows. The positive coefficient of this variable $(0.55677)$ indicates a direct relationship between the ratio of issued stocks and accumulated cash flows so, with the increase of the issued equity ratio by 1 unit, the accumulated cash flow also increased by 0.556 units. Also, since the probability of $t$ statistic for the coefficient of variation is less than 
12

$0.05(0.0234)$, it indicates a significant and direct effect of this variable on the relationship between the ratio of issued stocks and accumulated cash flows. Therefore, it can be concluded that, based on the analysis performed in support of the first hypothesis of the study there is a significant and direct relationship between the ratio of issued stocks and the accumulated cash flows of companies according to the price coefficient. The results of the second hypothesis of our study are consistent with the findings of Caballero et al. (2016), Costodio (2010) and contradict the findings of Almida et al. (2014) and Barrow (1990).

Table 2 - Test results of the second research hypothesis using the fixed effects method

\begin{tabular}{c|c|c|c|c}
\hline \multicolumn{5}{c}{$\begin{array}{r}\text { Dependent variable: accumulated cash flows } \\
\text { Views: 660 years - Company }\end{array}$} \\
\hline Variable & Coefficient & T & P-Value & Relation \\
\hline $\begin{array}{c}\text { Fixed } \\
\text { component }\end{array}$ & 0.6013 & 0.3942 & 0.0001 & Positive \\
\hline $\begin{array}{c}\text { Q Tobin Ratio } \\
\text { Profitability } \\
\text { ratio of capital } \\
\text { expenditure }\end{array}$ & -0.0748 & -5.6647 & 0.0000 & Negative \\
\hline $\begin{array}{c}\text { Cash Flow } \\
\text { Ratio of stocks } \\
\text { issued }\end{array}$ & -0.11 .7 & -7.6472 & 0.0000 & Negative \\
\hline $\begin{array}{c}\text { Contrast the } \\
\text { ratio of }\end{array}$ & 0.5677 & 4.0447 & 0.0001 & Positive \\
$\begin{array}{c}\text { published stocks } \\
\text { and the price } \\
\text { coefficient }\end{array}$ & 1.2431 & 4.7769 & 0.0000 & Positive \\
\hline $\begin{array}{c}\text { Cash capital } \\
\text { ratio }\end{array}$ & 0.1781 & 6.9285 & 0.0000 & Positive \\
\hline $\begin{array}{c}\text { Price } \\
\text { coefficient }\end{array}$ & 0.0182 & 1.2232 & 0.0234 & \\
\hline & & & & \\
\hline
\end{tabular}




\section{Conclusion}

The purpose of this study is to investigate the relationship between capital expenditures, stocks and cash flows of companies with respect to the price coefficient of each share. This research is a library and analytical-scientific study based on panel data analysis (panel data). In this study, financial information of 101 listed companies in Tehran Stock Exchange during the period 1391 to 1396 was reviewed (660 companies - year). Based on the correlation and regression tests and analyzes performed to confirm the first hypothesis of the study, we concluded that: There is a significant and direct relationship between cash flows and capital expenditures of companies with respect to price coefficient. We also concluded that, in support of the second hypothesis of the study, there is a significant and direct relationship between the ratio of issued stocks and the accumulated cash flows of companies according to the price coefficient. The results of this study are in line with the results of the research conducted by Flora and Harris in 2017 and the Castroidos in 2014. Castrido investigated the relationship between cash-flow sensitivity and investment spending by selecting 7,176 firms listed on the New York Stock Exchange from 1995 to 2013. They found that cash flow sensitivity was associated with both less-than-reality investments at a time when cash flows were low and more than real-time investment when cash flows were high. The ability to fund outside the company has a positive correlation with cash flows and enhances the sensitivity of cash flows. The results of research conducted in different countries show that the same generalizable results regarding the relationship between corporate cash flows, capital expenditures and stocks cannot be achieved with respect to the price coefficient rather, this impact is mainly related to the specific economic, cultural, social and political conditions of the countries, and each country has its own circumstances. In this study, managers are recommended to: Examine factors such as macroeconomic conditions and industry-specific environments, changes in accounts receivable, changes in capital expenditure, changes in profit margins, changes in administrative and sales costs, changes in technology and quality of earnings. It is also suggested that researchers conduct a similar research in a different time domain and compare its results with those of this study. 
14

\subsection{Research Limitations}

Naturally, every research will face obstacles and problems. One of the most common limitations of research in Iran, especially in the area of finance and accounting, is the difficulty of obtaining complete and easy access to the information required for research, this research has also been affected by this limitation. Other limitations of this study include the following: -The present study uses data from 101 stock companies and does not include all companies listed on the Tehran Stock Exchange. So be cautious when generalizing results to other companies.

- Inflation makes financial statements unable to accurately represent the company. Therefore, taking into account the effect of inflation may produce different results.

- This study is limited to the time slice from 2012 to 2016 and should be considered with caution and precision when generalizing its results to other time slices.

\subsection{Suggestions}

- Investigating the Relationship between Cash Flows, Capital Expenditures and the ratio of issued shares with regard to price using Intermediate Financial Statements.

-Investigating the Relationship between Cash Flows, Capital Expenditures and the Ratio of Issued Shares with Regard to Price Factor in Different Industries and Comparing Each Other.

\section{References}

Abadie, A., Imbens, G. (2006). Large sample properties of matching estimators for average treatment effects. Econometric 74, 235-267.

Abbasi, A. (2014). "The Impact of Prize Shares on the Stock Return Rate of Companies Listed in Tehran Stock Exchange", Tehran Management School under the guidance of Ali Jahankhani (M.Sc.).

Aghaie, Mohammad Ali et al. (2009). Investigating the Factors Affecting Cash Flow 
Maintenance in Companies Listed in Tehran Stock Exchange, Journal of Financial Accounting Research, vol. 1 and 2, pp. 70-53.

Almeida, H., Campello, M. (2014). Financing frictions and the substitution between internal and external funds. Journal of Financial and Quantitative Analysis 45, 586-622.

Anderson, K., Brooks, C., Katsaris, A. (2017). Speculative bubbles in the S\&P 500: Was the tech bubble confined to the tech sector?. Journal of Empirical Finance 17, 345-361.

Babajani, Mohammad. (2012). "Investigating the Impact of Cash Flow Uncertainty and also the Ratio of Earnings to Equity (as an indicator of Corporate Maturity) on Corporate Split Policy" Financial Accounting Research, No. 1, pp. 96-77.

Barro, R., 1990. The stock market and investment. Review of Financial Studies 3, 115-131.

Biddle, Gary, Gilles Hilary and Rodrigo. S Verdi. (2015)."How does financial reporting quality relate to investment efficiency?", Journal of Accounting and Economics, Volume 48.

Brooks, C., Katsaris, A. (2016). Trading rules from forecasting the collapse of speculative bubbles for the S\&P 500 composite index. Journal of Business 78, 2003-2036.

Brunnermeier, M., Nagel, S. (2004). Hedge funds and Earning per share. Journal of Finance 59, 2013-2020.

Caballero, R., Farhi, E., Hammour, M. (2016). Speculative growth: hints from the U.S. economy. American Economic Review 96, 1159-1192.

Campbell, J., Shiller, R. (2000). Integration and tests of present value models. Journal of Political Economy 95, 1062-1088.

Campello, M., Graham, J., Harvey, C. (2010). The real effects of financial constraints: evidence from a financial crisis. Journal of Financial Economics 97, 470-487.

Casser, Gavin John. (2015). External financing and firm operating performance, Working Paper, University of Califrnia, Berkeley.

Chen, M.C, cheng, S.J. and Hwang, Y. (2005). "An empirical investigation of the relationship between Intellectual capital and firm's market value and financial performance", Journal of Intellectual capital, Vol. 6 No. 2, pp. 159-176.

Chirinko, R., Schaller, H. (2011). Fundamentals, misevaluation, and investment. Journal of Money, Credit and Banking 43, 1423-1442.

Cummins, J., Hasset, K., Oliner, S. (2016). Investment behavior, observable expectations, and internal funds. American Economic Review 96, 796-810.

Custodio, C. (2010). Mergers and acquisitions accounting can explain the diversification discount. Unpublished working paper. Arizona State University. 
16

Fakhari Hussain, Taqavi Seyyed Ruhollah. (2015). The quality of accruals and cash balances. Accounting and auditing reviews

Fama, E., French, K. (2015). Financing decisions: Who issues stocks?. Journal of Financial Economics 76, 549-582.

Faulkender, M., Petersen, M. (2006). Does the source of capital affect capital structure? Review of Financial Studies 19, 45-79.

Fazzari, S., Hubbard, R., Petersen, B. (1988). Financing constraints and corporate investment. Brookings Papers on Economic Activity 1, 141-195.

Fischer, S., Merton, R. (2013). Macroeconomics and finance: the role of the stock market. Carnegie-Rochester Conference Series on Public Policy 21, 57-108.

Frank, M., Goyal, V. (2003). Testing the pecking order theory of capital structure. Journal of Financial Economics 67, 217-248.

Gordon, R. (2000). Does the 'new economy' measure up to the great inventions of the past? Journal of Economic Perspectives 14, 49-74.

Goyal, V., Yamada, T. (2014). Asset price shocks, financial constraints, and investment: evidence from Japan. Journal of Business 77, 175-199.

Griffen, S., Himmelberg, C., Huberman, G. (2015). Do stock price bubbles influence corporate investment? Journal of Monetary Economics 52, 805-827.

Heaton, J., Lucas, D. (2001). Stock prices and fundamentals. In: Bernanke, B., Rotemberg, J. (Eds.), NBER Macroeconomics Annual, MIT Press, Cambridge, pp. 213-242.

Hodrick, R., Prescott, E. (1997). Post-war U.S. business cycles: an empirical investigation. Journal of Money, Credit and Banking 29, 1-16.

Hosseinpour, Zahra. (2005). Investigating the Relationship between Effective Factors and Investment-Cash Flow Sensitivity in Companies Listed in Tehran Stock Exchange, MSc Thesis, Faculty of Administrative Sciences and Economics, University of Isfahan.

Hovakimian, A., Opler, T., Titman, S. (2011). The debt-equity choice. Journal of Financial and Quantitative Analysis 36, 1-24.

Jensen, M. (2005). Agency costs of overvalued equity. Financial Management 34, 5-19.

Jermann, U., Quadrini, V. (2018). Stock market boom and the productivity gains of the 1990s. Journal of Monetary Economics 54, 413-432.

Kanani, M. (2015). Determining the Relationship between Capital Expenditure with Q Factor and Future Stock Return in Companies Listed in Tehran Stock Exchange. 
Kashani Pour, Mohammad, Naghi Nejad, Bijan. (2017). Investigating the effect of financial constraints on cash flow sensitivity, Accounting Research, Vol 2, pp. 93-72.

Mirfakhruddin Seyed Haidar, Moeinuddin Mahmood, Ebrahimpour Alireza. (2016). Comparison of the ability of cash flows and accruals to predict future cash flows Accounting and Auditing Reviews

Moradi, Javad, Ahmadi, Gholamreza. (2018). Determining Factors Influencing Corporate Investment Behavior in the Field of Incomplete Markets - Journal of Financial Accounting Research - Third Year - Second Issue - Summer 90 - Pages 136-125.

Myers, S., Majluf, N. (1984). Corporate financing and investment decisions when firms have information those investors do not have. Journal of Financial Economics 13, 187-221.

Ofek, E., Richardson, M. (2013). Dotcom mania: the rise and fall of internet stock prices. Journal of Finance 58, 1113-1128.

Pastor, L., Veronesi, P. (2018). Was there a stock price bubbles in the late 1990s? Journal of Financial Economics 81, 61-100.

Poterba, J. (1998). Population age structure and asset returns: an empirical investigation. NBER Working Paper No. 6774.

Soleimani, H. (2016). "Investigation of the Relationship between Cash Flow Statement Changes and Stock Return Changes in Companies Listed in Tehran Stock Exchange", Islamic Azad University of Boroujerd Branch under the guidance of Hassan Jannani, M.Sc.

Tabibi Rad, Wahideh. (2013). Investigating the Information Content of the Operating Cash of Each Share and Comparing it with the Earnings of Each Share; Thesis (MSc) - AlZahra University (S) - Guidance: Mahnaz Melanazeri; Advisor Professor: Rezvan Hejazi 